\begin{tabular}{|c|c|c|c|}
\hline \multicolumn{4}{|l|}{$\begin{array}{l}\text { Editor } \\
\text { Joe Bouch }\end{array}$} \\
\hline $\begin{array}{l}\text { Editorial Board } \\
\text { Gwen Adshead } \\
\text { J.S. Bamrah } \\
\text { Dinesh Bhugra } \\
\text { Nick Brown } \\
\text { Alistair Burns } \\
\text { Patricia Casey } \\
\text { John Cookson } \\
\text { Colin Drummond } \\
\text { Jonathan Green }\end{array}$ & $\begin{array}{l}\text { Sheila Hollins } \\
\text { Cornelius Kator } \\
\text { Helen Killaspy } \\
\text { David Owens } \\
\text { Femi Oyebode } \\
\text { Jan Scott } \\
\text { Tom Sensky } \\
\text { Steven Sharfste } \\
\text { Peter Tyrer } \\
\text { David Yeomans }\end{array}$ & $\begin{array}{l}\text { Senio } \\
\text { Lynne } \\
\text { Staff } \\
\text { Kasia } \\
\text { Zosia }\end{array}$ & $\begin{array}{l}\text { orial Assistant } \\
\text { ca Thomas } \\
\text { ior Staff Editor } \\
\text { ette Maddock } \\
\text { f Editors } \\
\text { a Krawczyk } \\
\text { O'Connor }\end{array}$ \\
\hline \multicolumn{4}{|c|}{$\begin{array}{l}\text { Subscriptions } \\
\text { Advances Volume 15, } 2009 \text { (six issues) } \\
\text { (full airmail f19/US\$34 extra) }\end{array}$} \\
\hline & $\begin{array}{l}\text { Members of the } \\
\text { Royal College } \\
\text { of Psychiatrists }\end{array}$ & Non-members & Institutions \\
\hline \multicolumn{4}{|c|}{ Print (+free on-line) } \\
\hline Europe (\& UK) & $f 60$ & £126 & $£ 141$ \\
\hline USA & US\$107 & US\$199 & US\$243 \\
\hline $\begin{array}{l}\text { Elsewhere } \\
\text { On-line (only) }\end{array}$ & \multicolumn{2}{|c|}{ On-line (only) } & $£ 152$ \\
\hline Worldwide & £38/US\$61 & f100/US\$150 & f128/US\$199 \\
\hline
\end{tabular}

Payment may be made by cheque/money order, by Access/Master Card/ Visa/American Express, or by UNESCO coupons. EC subscribers: please supply your Member State Code and Value Added Tax (VAT) number.

Payment should be made to Maney Publishing, Suite 1C, Joseph's Well, Hanover Walk, Leeds LS3 1AB, UK (tel: +44 (0)113 243 2800; fax: +44 (0)113 386 8178; email: subscriptions@maney.co.uk). For subscriptions in North America, please contact Maney Publishing North America, 875 Massachusetts Avenue, 7th Floor, Cambridge, MA 02139, USA (tel: 866 2975154 (toll free); fax: 617354 6875; email: maney@maneyusa.com). Continuing professional development (CPD) Those wishing to register for CPD with the Royal College of Psychiatrists should contact the CPD unit (tel: +44 (0)20 72352351 , ext. 112 or 108). There is no charge for participation in the CPD scheme for Members, Fellows and Affiliates of the College.

CPD Online The College also publishes an interactive online learning facility for CPD in psychiatry. Further details, sample modules and subscription information can be viewed at www.psychiatrycpd.co.uk. Discounts are available for Advances subscribers.

Correspondence Letters submitted for publication should be emailed to Dr Joe Bouch at apt@rcpsych.ac.uk or posted to Advances in Psychiatric Treatment, Royal College of Psychiatrists, 17 Belgrave Square, London SW1X 8PG.

Printed by Henry Ling Ltd, 23 High East Street, Dorchester, Dorset DT1 1 HD.

(C) The Royal College of Psychiatrists 2009. Published by the Royal College of Psychiatrists, a charity registered in England and Wales (228636) and in Scotland (SC038369). Unless so stated, material in Advances in Psychiatric Treatment does not necessarily reflect the views of the Editor or the Royal College of Psychiatrists. The publishers are not responsible for any errors of omission or fact.

The College crest is a registered trade mark of the Royal College of Psychiatrists.

ISSN 1355-5146

\section{Risk and professionalism}

\author{
By Joe Bouch
}

In uncertain times for psychiatrists and for the medical profession in general, defining roles and responsibilities is proving to be a complex task. Yet, as clinicians grapple with multidisciplinary and multiagency teamwork, one expectation of consultant psychiatrists has become clear - their central role in assessing and managing risk. For many of us this is both challenging and uncomfortable. It is also under threat from 'the growth of risk management strategies that displace valuable - but vulnerable - professional judgement in favour of defendable process' (Power 2004: pp. 10-11).

Downie \& Macnaughton (pp. 322-327) distinguish between theoretical and practical professional judgements. In addition to asserting 'what is probably true or correct' we have to decide 'what we ought to do'. Such judgements are always made in conditions of uncertainty, albeit informed by the evidence base and 'reasonable considerations'. Thornton (pp. 328-331) agrees that clinical judgement is 'at the heart of good clinical practice'. The crux of the matter is seeing when 'a general concept applies to an individual person'. Downie \& Macnaughton outline further threats to professional judgement - the false securities of 'objective' reductionist approaches and an undermining of the professional role in a consumerist culture. But they also highlight how professional judgement may be safeguarded and developed. Knowledge and skills in diagnosis, treatment and ethics are vital but they pay special attention to attitudes. Here, 'broad education ... in humane values' is essential to developing the necessary breadth of perspective, curiosity and flexibility of mind. Such a broad educational agenda is one to which Advances can make an important contribution by presenting the evidence, teasing out the ethical issues and practical implications, and featuring the medical humanities.

Our front cover accompanies the article by Lopez Gaston et al (pp. 344353). This photograph, published with the patient's permission, is a vivid illustration of a less often considered risk - the unintended hazards resulting from compulsive hoarding. This is just one of the secondary risks relating to obsessive-compulsive disorder considered by Veale et al, my Editor's Pick.

\section{Risk and OCD}

Veale et al's article (pp. 332-343) brings together an authorship of uncommon bedfellows - practitioners working in young peoples' and in adult services, psychologists and psychiatrists, clinicians and academics. Such interdisciplinary collaboration is fully in the spirit of Advances. The authors inform us that, although 'there are no recorded cases of a person with OCD carrying out their obsession', numerous secondary risks derive from the meaning attached to intrusive thoughts and the response to them. One such risk, played out in therapeutic relationships, is the 'transmission of obsessional worries from the patient to the clinician'. Few clinicians would not experience at least a frisson of anxiety and doubt if a patient with OCD who works with children asked them, 'Are you 100\% confident that my intrusive sexual thoughts are obsessional rather than something else?'.

Power, M (2004) The Risk Management of Everything: Rethinking the Politics of Uncertainty. Demos (http://www. demos.co.uk/files/riskmanagementofeverything.pdf). 